Marcin Kafar*

Izabela Kamińska-Jatczak $^{* *}$

\title{
W kręgu transgeneracyjnych biografii naukowych. \\ Zaczynając od Heleny Radlińskiej i Kazimiery Zawistowicz-Adamskiej
}

\begin{abstract}
Abstrakt
Tekst - zorientowany na odkrywanie sensów i znaczeń transgeneracyjnych biografii naukowych - jest formą rozmowy dialogicznej toczącej się pomiędzy dwoma osobami przynależącymi do środowiska łódzkich pedagogów. On pojawił się w nim jako przybysz ze świata antropologii i etnografii, ona - pedagog społeczny - przywędrowała z kręgu terenowej pracy socjalnej z rodziną. Na przekór posiadaniu odrębnych rodowodów dyscyplinarnych, dialogowanie daje im szansę na rozpoznanie tropów wskazujących na istnienie między nimi doświadczeniowo-intelektualnego pokrewieństwa. Bazując na nim, wykonują współdzieloną pracę interpretacyjną, stopniowo odkrywając ślady prowadzące do zapoznanej przeszłości, gdzie etnografia i pedagogika społeczna spotykają się w osobach Heleny Radlińskiej i Kazimiery Zawistowicz-Adamskiej.
\end{abstract}

Słowa kluczowe: rozmowa dialogiczna, rozpoznawanie doświadczeń, nauka jako dziedzictwo kulturowe, tropy związków z twórczością i życiem Heleny Radlińskiej i Kazimiery Zawistowicz-Adamskiej.

\section{Transgenerational Scientific Biographies. The Beginnings: Encountering Helena Radlińska and Kazimiera Zawistowicz-Adamska}

\footnotetext{
Abstract

The article - focused on the exploration of the meanings of transgenerational scientific biographies - is a form of a dialogic conversation occurring between two members

* Uniwersytet Łódzki, Wydział Nauk o Wychowaniu, Katedra Badań Edukacyjnych.

** Uniwersytet Łódzki, Wydział Nauk o Wychowaniu, Katedra Pedagogiki Społecznej.
} 
of the society of Łódź pedagogues. He - emerged in this society as a newcomer arriving from the world of anthropology and ethnography. She - a social pedagogue made her way there from the circle of the family social work field. In spite of having different disciplinary origins, carrying on a dialog gives them a chance to recognize the paths indicating the existence of their common intellectual and experiencerelated connections. Using these common links, they work together on the interpretation and gradual detection of the signs of unacknowledged past, where ethnography and social pedagogy meet the foundations set by Helena Radlińska and Kazimiera Zawistowicz-Adamska.

Keywords: dialogic conversation, recognition of the experience, Humanities and Social Sciences as cultural heritage, signs of the connection to the work and life of Helena Radlińska and Kazimiera Zawistowicz-Adamska.

Tekst jest próbą wstępnego zmierzenia się z fenomenem transgeneracyjnych biografii naukowych ${ }^{1}$, dla których, w analizowanym przypadku, podstawowym obszarem rozpoznań czynimy złożony układ doświadczeń własnych („Izabeli Kamińskiej-Jatczak”, „Marcina Kafara”) i zapośredniczonych, ucieleśnionych w osobach Heleny Radlińskiej oraz Kazimiery Zawistowicz-Adamskiej.

Za tym dość lapidarnie brzmiącym określeniem przedmiotu zainteresowań stoją konkretne założenia dotyczące rozumienia nauki i sposobów jej funkcjonowania. Nasze stanowisko mieści się w horyzoncie konstruktywistycznym, stanowiąc wariant „nie-klasycznego” podejścia do praktyk naukowych. W proponowanym ujęciu na pierwszy plan wysuwają się podmiotowe aspekty aktywności, zyskujące status działań równoważnych względem - uznawanych w podejściu „klasycznym" za nadrzędne - elementów składających się na przestrzeń myśli (idei).

Posługując się rozróżnieniem podejścia do nauki na „klasyczne” i „nie-klasyczne", nawiązujemy, z pewnymi zastrzeżeniami wynikającymi z charakterystyczności przedstawianej tu opcji, do ustaleń poczynionych w ramach badań nad historią nauki, rozwijanych albo jako samodzielne studia w ramach filozofii nauki, socjologii wiedzy, antropologii wiedzy czy naukoznawstwa, albo jako studia uzupełniające wielu dyscyplin należących do korpusu nauk społecznych i humanistycznych (w tym przede wszystkim socjologii, historii i antropologii, od pewnego

\footnotetext{
1 Pod pojęciem biografii/autobiografii naukowej rozumiemy wielorakie formy wypowiedzi auto/biograficznych (zarówno pisemnych, jak i ustnych) zawierających treści zorientowane na skorelowane ze sobą współdziałanie trzech elementów, a mianowicie: (i) podmiotu jednostkowego; (ii) podmiotu wspólnotowego oraz (iii) dyskursu. Aby było możliwe rozpoznanie owych treści jako należących do wymiaru biografii/autobiografii naukowej, koniecznym jest umiejscowienie w nich (poprzez opowieść ustną lub pisemną) aspektów doświadczeń/aktywności podmiotu jednostkowego, które współzależne są w różnym zakresie z doświadczeniami/aktywnością podmiotu wspólnotowego i/lub dyskursu jako efektu tychże zależności (definicja własna - MK). Powyższe zdefiniowanie biografii/autobiografii naukowej mieści się w horyzoncie metateoretycznym, dopuszcza w związku z tym opcję wyodrębniania szczegółowych przedmiotów zainteresowań badawczych, a także adekwatnych względem nich sposobów ujęcia podejmowanej problematyki. Rozszerzone konotacje znaczeniowe użytego tu pojęcia „biografii naukowej” znajdują się w następujących pracach: Kafar (2016, 2013a, 2011a).
} 
czasu - także, w kontekście polskim, pedagogiki (por. m.in. Kubinowski 2013, 2012, 2010, 2006; Marynowicz-Hetka 2015, 2004, 1997; Marynowicz-Hetka, Theiss 2004; Nowak 2006; Rembierz 2013, 2012)). Tłumacząc rzecz w skrócie, można stwierdzić, iż w obrębie ujęcia „klasycznego” patrzymy na naukę jako dziedzinę wyłączoną poza obszar kultury i działań społecznych, jednocześnie zrośniętą z pozytywistycznym ideałem badań przyrodoznawczych, z naczelną dla niego funkcją technologiczną. Na przeciwległym - „nie-klasycznym” - biegunie sytuuje się podejście wsparte o pogląd, iż nauka, podobnie jak sztuka, religia czy szeroko rozumiana ideologia jest integralną częścią świata kultury i człowieka jako istoty biorącej czynny udział w tworzeniu owego świata w wymiarze ponadjednostkowym społecznym (Kmita 1976, 1985). Dodajmy, że tradycja przeciwstawiania nauki kulturze nazywana bywa „platońską”, zaś tradycja zakładająca istnienie splotu nauki z kulturą i człowiekiem nosi miano „arystotelesowskiej” (Wrzosek 1995: 7). O ile pierwszą z nich cechuje determinizm docierania do „prawdy obiektywnej”, o tyle druga bazuje na przesłaniu współtworzenia przestrzeni dialogicznej powołującej do życia prawdę wewnątrzwspólnotową, międzyosobową i międzywspólnotową (a więc także międzygeneracyjną).

Zawężając pole tematyczne do obszaru nas zajmującego, postrzegamy fenomen transgeneracyjnych biografii naukowych jako mocno zrośnięty z problemem temporalności odnoszącej się do specyficznej natury zjawisk „organizujących pole wiedzy" (Marynowicz-Hetka 2015: 16). Ewa Marynowicz-Hetka, posiłkując się ustaleniami Gastona Bachelarda, Michela Foucaulta oraz, bodaj w największym stopniu, Ferdynanda Braudela², przekonuje, że „rozwój zjawisk nie dokonuje się linearnie, lecz poprzez zerwania i nieciągłości” oraz że - co bezpośrednio wynika z powyższego - przeszłość pożytkujemy „nie w sensie chronologicznym i linearnym, ale jako tło/kontekst dla tego co najważniejsze dla zrozumienia teraźniejszości i antycypowania przyszłości" (tamże). Nieco dalej czytamy:

Zaznajomienie się z metodą F. Braudela (...), uwzględniającą odnajdywanie tych elementów/zdarzeń, które pozwalają egzemplifikować linie „długiego trwania” (longue dureé), pozwala wyobrazić sobie możliwość takiego pojmowania przeszłości, w którym przerwy, fragmentaryzacje i nieciągłości (discontinuités) dają możliwość rekonstytuowania debat organizujących pole wiedzy. Na tym tle można stawiać pytania o miejsce przeszłości, usytuowanej w teraźniejszości i jej znaczenie dla strukturowania przyszłości. Tak formułowane pytanie pozwala także na analizę nie tyle (nie tylko) zdarzeń przeszłości, ale „pochodzenia/genealogii” (w znaczeniu foucaultowskim) aktualnych zjawisk społecznych usytuowanych w kontekście społecznym (tamże).

\footnotetext{
2 Do tego zacnego grona warto byłoby jeszcze dołączyć Olivera Sacksa, brytyjskiego neurologa i historyka nauki, twórcę metafory „naukowych skotom”, czyli „mroczków”, zbiorowych „przesłonięć” pamięci, od których, jeśli wierzyć autorowi wizjonerskiego eseju pt. Mroczek: zapominanie i pomijanie w nauce, nie jest wolna żadna dziedzina (por. Sacks 1996).
} 
Stanowisko Ewy Marynowicz-Hetki daje się umiejscawiać na dwóch poziomach: pierwszym jest poziom uniwersalny (obejmujący mechanizmy ogólnokulturowe), drugim - partykularny, dotyczący szczególnej dziedziny kultury, jaką jest wiedza naukowa, włączając w to także społeczne warunki jej kształtowania. 0 ile poprawnie odbieramy intencję autorki, jej głos przynależy do poziomu drugiego, nadto jest głosem splecionym z jednoznacznie zdefiniowanym polem wiedzy, a mianowicie pedagogiką społeczną. Znamienne, że ustępy przez nas komentowane znalazły się w artykule otwierającym część I monografii pt. Pedagogika społeczna: wstępy i kontynuacje (Marynowicz-Hetka, Skoczylas-Namielska 2015). Nie bez przyczyny Ewa Marynowicz-Hetka zaznacza, iż taki, a nie inny tytuł został sformułowany „jeszcze przez Profesor Irenę Lepalczyk”, dodając: „Mówienie o wstępach i kontynuacji, a nie tradycyjnych aspektach dyskursu czy praktyk, wyrażało (...) powściągliwość prawdopodobnie uzasadnioną doświadczanymi zerwaniami i nieciągłościami w rozwoju pedagogiki społecznej zarówno dyscyplinarnym, jak i instytucjonalnym"4.

Mało kto wie, że tropy jednego z najbardziej tajemniczych zerwań, do jakich doszło na przestrzeni ponad wiekowego, „nieciągłego” rozwoju pedagogiki społecznej, prowadzą do etnografii. Przez kilka dekad, poczynając od przedwojnia, dyscypliny te pozostawały w nieznacznym od siebie oddaleniu. Kiedy jako reprezentanci średniego i młodego pokolenia, odpowiednio etnografów-antropologów (Marcin Kafar) oraz pedagogów społecznych (Izabela Kamińska-Jatczak), odkryliśmy źródła świadczące o intensywnych kontaktach utrzymywanych dawniej między przedstawicielami - dla nas, dzisiaj - całkiem odrębnych dyscyplinarnie światów, byliśmy ogromnie zaskoczeni. Łączone programy studiów, uczestnictwo studentów pedagogiki w etnograficznych ćwiczeniach terenowych ${ }^{5}$, zespołowa, etnograficzno-pedagogiczna praca nad koncepcjami badań - wszystko to potwierdzało istnienie spójnego „kolektywu myślowego”, środowiska akademickiego, które... (Nagle? Stopniowo?) zamarło.

„Co zadecydowało o zaniku tamtej wspólnoty? Jakie okoliczności sprawiły, że wcześniejsze zbliżenie pokrył gęsty mrok niepamięci7?” - zastanawialiśmy się,

\footnotetext{
${ }^{3}$ Ewa Marynowicz-Hetka była uczennicą Ireny Lepalczyk, w 1987 r. przejęła po tej ostatniej kierownictwo Katedry Pedagogiki Społecznej UŁ.

${ }^{4}$ W Przedmowie do tego samego tomu jego współredaktorki, Ewa Marynowicz-Hetka i Elżbieta Skoczylas-Namielska (2015b: 7), piszą zaś: „Tytuł (...) Pedagogika społeczna: wstępy i kontynuacje - ma swoją historię. Taki nagłówek nosił ostatni konspekt książki, którą Profesor Irena Lepalczyk zamierzała przygotować. Podjęte zostały wstępne rozmowy i ustalenia. Jednak nie zdążono zebrać materiałów przed odejściem Pani Profesor. Na długo zamysł ten został odsunięty ze względu na różne, stale pilne, sprawy bieżące. Tym tomem, powrotem do tamtego tytułu zamierzonej publikacji, spłacamy dług i równocześnie pracując nad tekstami, powracamy mentalnie do dyskusji na temat tej książki".

${ }^{5}$ Partycypowała w nich m.in. Irena Lepalczyk. W zbiorze fotografii zamieszczonym na końcu jej Wśród ludzi i ksiq̨żek, zdjęcie znajdujące się pod numerem 33. opatrzone jest następującą legendą: „Ze wstępu do ludoznawstwa wraz z ćwiczeniami otrzymałam ocenę celujacq. Z prof. Kazimierą Zawistowicz (stoi trzecia od lewej) podczas ćwiczeń w terenie” (Lepalczyk 2003: 320; zapis zgodny z oryginałem).

${ }^{6}$ Terminu „kolektyw myślowy” używamy za Ludwikiem Fleckiem (1986).

${ }^{7}$ Jak bardzo jest on obecnie nieprzenikniony, przekonaliśmy się, sondując pamięć wybranej grupy profesorów z Wydziału Nauk o Wychowaniu UŁ. Nikt z naszych rozmówców nie słyszał ani o zaprzeszłej bliskości powiązań etnografii i pedagogiki społecznej, ani też o relacjach Heleny Radlińskiej z Kazimierą Zawistowicz-Adamską.
} 
pochylając się nad archiwaliami i wertując publikacje dające pewne wyobrażenie

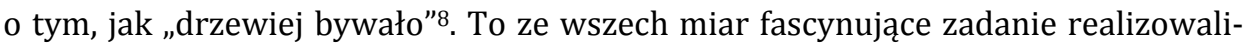
śmy równolegle $\mathrm{z}$ innym - analityczno-interpretacyjną rekonstrukcją śladów wiodących do zapoznanej przeszłości pedagogiki społecznej/etnografii. Otwierając się na ułatwiające rozwój i transgresję „procesualnie zarysowane linie długiego trwania” (tamże), podjęliśmy wyzwanie dialogowania z samymi sobą i naszymi antenatkami - Heleną Radlińską oraz Kazimierą Zawistowicz-Adamską. A oto, co dzięki niemu osiągnęliśmy...

Marcin KAFAR: Izo, sądzę, że na początek warto przybliżyć Czytelnikowi tło zrodzenia się pomysłu na napisanie niniejszego tekstu9

Izabela KAMIŃSKA-JATCZAK: Według mnie wyrasta on z naszej wspólnej pracy nad książką Auto/biograficzne aspekty praktyk poznawczych (Kafar 2016), monografii, gdzie spotkaliśmy się jako współautorzy tekstów, choć nie tylko.

MK: Zgadza się. Jako redaktor naukowy tamtej publikacji miałem szczęście zapoznać się z roboczą wersją twojego artykułu pt. $O$ (nie)udanej próbie odnalezienia się w roli praktykującego badacza. Refleksje z pola praktyki (Kamińska 2016). Metodyka, jaką stosuję przy redagowaniu tekstów innych autorów, sprzyja tzw. głębokiej lekturze. Tak było również w przypadku twoich Refleksji z pola praktyki.

IKJ: Pamiętam, że dostałam od ciebie, Marcinie, sześć lub siedem kolejnych wersji mojego artykułu, to naprawdę była, jak mówisz, „głęboka lektura”. [śmiech]

MK: Dla mnie ważne są motywacje stojące za takimi posunięciami. Zawsze staram się harmonijnie, a zarazem twórczo zorkiestrować z tekstem, który czytam, w ten

\footnotetext{
${ }^{8} \mathrm{Na}$ podstawie materiałów zebranych w tym zakresie powstanie osobny artykuł.

${ }^{9}$ Druga część artykułu została przygotowana w formie rozmowy-dialogu. 0 przyjęciu takiego rozwiązania zadecydowało głównie przekonanie, że stosując tradycyjny typ wypowiedzi naukowej, nie zdołamy utrzymać w tekście pozycji, w jakich występowaliśmy/występujemy względem siebie w życiu pozatekstualnym. Jest to o tyle istotne, że pozycje te kształtują profil analityczno-interpretacyjnych narzędzi, jakimi się posługujemy, w tym sensie poczyniony zabieg zyskuje mocne uzasadnienie metodologiczne. Nasza rozmowa-dialog została zbudowana wokół osnowy tematycznej, której morfologia - mówiąc językiem strukturalizmu - wyklucza przypadek. Tak więc, Gadamerowski duch rozmowy nieustannie szuka tutaj kompromisu z duchem naukowej argumentacji w starym stylu. Stąd też, czytelnik zagłębiający się w poszczególne odsłony wypowiedzi napotka różne gatunkowo warstwy. Będzie się przemieszczał między fragmentami o zabarwieniu eseistycznym, hermeneutycznie sankcjonowaną analizą tekstu, wreszcie - osobistym wspomnieniem przyjmującym postać „małej autobiografii intelektualnej” (patrz Kafar, Rydlewski 2016a: 157-158, s. 4.).

W uzupełnieniu do powyższych objaśnień dodajmy, iż znaną już w starożytności (por. Platon 1982), praktykowaną także w wiekach nowożytnych (w odmianie nauki Galileuszowskiej (Namer 1985)) formułę rozmowy-dialogu, współcześnie wykorzystywali tacy badacze, jak chociażby Ludwik Fleck ([1938] 2007a), Paul Ricoeur (2003a), Michel Foucault (1977) czy - unoszący się na fali zwrotu refleksywnego w naukach społecznych - Pierre Bourdieu (2001). Na gruncie polskim, pisanie artykułu naukowego w tej konwencji uskuteczniali: Tomasz S. Markiewka wraz z Pawłem Bohuszewiczem (2014) oraz Marcin Kafar wespół z Carolyn Ellis (2014) i Michałem Rydlewskim (2016a, 2016b, 2016c).
} 
sposób próbując nawiązać nić porozumienia także z kimś, kto ten tekst powołał do życia. Tego typu postawę określiłbym jako otwarcie dialogiczne. Redaktor naukowy często bywa pierwszym czytelnikiem czyjegoś dzieła, jest jednocześnie kimś, na kim spoczywa ogromna odpowiedzialność za jego upublicznienie w odpowiedniej postaci. Oczywiście, owo „otwarcie dialogiczne” raz bywa podejmowane, kiedy indziej, z różnych powodów, nie.

IKJ: A co się stało w naszym przypadku?

MK: Oboje wiemy, Izo, że to pytanie jest w dużej mierze retoryczne, skoro dziś, po upływie paru miesięcy nadal ze sobą rozmawiamy. [śmiech]

IKJ: Dla mnie istotne jest to, że dzisiejsza rozmowa stanowi kontynuację rozmów odbytych wcześniej, i - chyba przede wszystkim - że dzieje się to w sposób niewymuszony.

MK: Otóż to! Przypuszczać należy zatem, iż ty jako autorka i ja jako odbiorca-redaktor umieliśmy znaleźć drogę do siebie. Zresztą, jestem przekonany, że gdybyśmy pokusili się o dokonanie choćby tylko całkiem pobieżnej retrospekcji, bez kłopotu udałoby się nam wskazać i dookreślić miejsca styczne, zworniki, pozwalające tej rozmowie rozwijać się aż do teraz.

IKJ: Domyślam się, że masz na myśli coś konkretnego...

MK: Tak. To, co powiem, dla ciebie nie będzie zaskoczeniem, natomiast w innej sytuacji znajduje się Czytelnik, który do tej pory nie brał udziału w procesie wzajemnych rozpoznań angażujących naszą dwójkę.

IKJ: Mhm.

MK: Zacznę od wspomnianej „głębokiej lektury” Refleksji z pola praktyki. To właśnie w jej trakcie zdałem sobie sprawę, że twoja praca zawiera płaszczyzny ujawniające istnienie między nami - pozwól, że posłużę się neologizmem - doświadczeniowo-intelektualnego pokrewieństwa.

IKJ: Poproszę cię o rozwinięcie tego wątku...

MK: Po pierwsze, opowiadasz o doświadczeniach samozwrotnych, tzn. takich, które wpływają na świadomość tego, kim byłaś, kim jesteś oraz kim się stajesz.

IKJ: To prawda. Tekst, o którym rozmawiamy powstał z potrzeby przeanalizowania czasu dla mnie przełomowego z punktu widzenia krystalizowania się mojej tożsamości pedagoga społecznego. Tkwiłam wtedy w niecodziennym usytuowaniu. Znajdowałam się między dwoma „światami” - akademickim i pozaakademickim. Kiedy w 2009 r. zaczynałam pracę na stanowisku asystenta w Katedrze Pedagogiki Społecznej Uniwersytetu Łódzkiego byłam już praktykiem terenowej pracy socjalnej (asystentem rodziny). Kłopot polegał głównie na tym, że nie wiedziałam, które usytuowanie z tych, w jakich się znajdowałam, uczynić konstytutywnym dla mojej 
tożsamości pedagogicznej. Zgodnie z tym, co opisuję w Refleksjach z pola praktyki, doświadczanie siebie $\mathrm{w}$ dwóch przestrzeniach modalności działania (praktyka i początkującego badacza) wymagało ciągłego odnajdowania się w odmiennych i, jak mi się wydawało, sprzecznych rolach. Mimo wszystko chciałam jakoś je ze sobą pogodzić; poszukiwałam więc formuły uwspólniającej, a zarazem scalającej moją „sobość” (Ricoeur 2003b: 33-34).

MK: Twoja historia mnie poruszyła. Może dlatego, że sam przeżywałem podobne rozterki kilkanaście lat wstecz, kiedy to długo nie umiałem pogodzić w sobie ról przedstawiciela Akademii i opiekuna ludzi mieszkających w jednym z łódzkich Domów Pomocy Społecznej, gdzie od 2004 r. prowadziłem badania terenowe (por. m.in. Kafar 2010a) ${ }^{10}$. Okazuje się, że pisząc swoje Refleksje z pola praktyki, trafiałaś w rdzeń spraw, które i mnie były bliskie.

IKJ: Chcesz powiedzieć, że niezależnie od siebie zatapialiśmy się w tej samej materii doświadczenia?

\section{MK: Zgadza się!}

IKJ: Co miałoby się na nią składać?

MK: Na ten moment, przedstawiając rzecz zwięźle, stawiałbym na zaplecze konceptualne i stojący za nim specyficzny typ osobowości badawczej, jaki skłonni jesteśmy dla siebie wybierać.

IKJ: Rozumiem, że wciąż pozostajemy w granicach twojej "głębokiej lektury" mojego artykułu?

MK: Tak. Decydująca w tej perspektywie jest dla mnie warstwa Refleksji z pola praktyki, gdzie sięgasz po rozstrzygnięcia epistemologiczne proponowane przez Kirsten Hastrup, współmierną względem niej w tym względzie Annę Wykę oraz podającą ci należyty słownik pojęciowy - i być może nie tylko on - Helenę Radliń-

\footnotetext{
10 Rozterki te dobrze obrazuje następujący opis: „Po raz kolejny staję przed bardzo poważnym dylematem: do czego w istocie powinna sprowadzać się moja obecność w życiu Domu i hospicjum? Pojawiłem się tutaj jako ktoś, kogo zadaniem jest gromadzenie danych w celach naukowych; i to przede wszystkim ja - jako Antropolog - będę beneficjentem pracy wykonywanej wespół ze mną przez grupę Mieszkańców. Mam jednak poczucie, iż z mej strony pozostaje do wypełnienia przestrzeń moralnych powinności wobec ludzi takich, jak Pan Zbyszek [jeden z pensjonariuszy DPS-u - przyp. MK]. Dla nich, stających na mojej drodze, typowe cele antropologiczne są bardzo odległe i niewiele wnoszą w powszedniość, wymagającą zupełnie innego rodzaju zaangażowania niż to, które dzierżę w podręcznym antropologicznym bagażu. W większości przypadków Oni potrzebują przede wszystkim płynącej z głębi serca troski i postępujących za nią konkretnych gestów, pozwalających choćby na krótko zapomnieć o mocno doskwierającym osamotnieniu czy braku nadziei na fizyczne wyzdrowienie. W jakim stopniu mogę Im to dać? Albo inaczej: w jakim stopniu (jeśli w ogóle) mogę Im to dać jako Antropolog? Coraz wyraźniej zaczyna dojrzewać we mnie myśl, że idę jednocześnie dwiema (współbieżnymi?, komplementarnymi?, rozszczepionymi?) ścieżkami. Jedną $\mathrm{z}$ nich kroczy posługujący się racjonalnymi narzędziami poznania Antropolog-Gromadzący Materiał Empiryczny (wiem, iż krytyczny sposób myślenia o hospicjum i Domu w przyszłości zaowocować może wiedzą dającą szansę na lepsze zrozumienie problemów nurtujących społeczności takie jak ta, w której dziś jestem), drugą - nieobojętny na los pojedynczego człowieka Antropolog-Początkujący Opiekun. Dokąd zaprowadzą mnie te drogi?" (Kafar 2010a: 263-264).
} 
ską. Dyskretnie wspiera cię jeszcze Paul Ricoeur, ale wydaje mi się, że centralne pole znaczeń rozciąga się między Hastrup, Wyką a Radlińską. Musisz przyznać, że, przynajmniej na pierwszy rzut oka, wgląda to na zaskakującą konfigurację osobową, ale czy taką jest w istocie?

IKJ: Rzeczywiście, łączne odnoszenie się do tych badaczek, biorąc pod uwagę ich odrębne usytuowanie dyscyplinarne (antropologia społeczna - socjologia - pedagogika społeczna), może dziwić. U Wyki, Hastrup i Radlińskiej znalazłam jednak synergię intelektualną, związaną z bardzo ważnym dla mnie postulatem zaangażowanej obecności badawczej. Jeśli pozwolisz, rozwinę nieco ten wątek.

MK: Bardzo proszę.

IKJ: Kiedy rozpoczynaliśmy naszą współpracę, byłam świeżo po lekturze Stosunku wychowawcy do środowiska społecznego Heleny Radlińskiej (1935). Pamiętam, że fragmenty tej książki, szczególnie ustępy o potrzebie „wżywania się” w środowisko (tamże: 75), a także słowa traktujące o tym, że - „osobistego uważnego wpatrywania się i wsłuchiwania nie zastąpią najbardziej pomysłowe ankiety" (tamże) przemówiły wprost do mnie. Zastanawiałam się, co mogło mieć wpływ na taki odbiór przesłania Radlińskiej. Ścieżka wiodła do moich doświadczeń z okresu bycia asystentem rodziny. Na co dzień nieustannie spotykałam się z człowiekiem, który miał mi coś do powiedzenia, niekoniecznie zresztą werbalnie. Czułam, że sens uczestnictwa tkwi w słuchaniu ludzi, a o to upominała się Radlińska! Domagała się, by odkrywać cudze środowiska - ich pojęcia, pragnienia, „istotę mocy duchowej” i więzy z szerszym światem (tamże). W trakcie pisania Refleksji z pola praktyki, zaczęłam stawiać pytania dotyczące tego, w jaki sposób da się wydobywać z siebie nastawienie poznawcze, sprzyjające procesowi „wżywania się”. Przypomniała mi się wówczas lektura pt. Badacz społeczny wobec doświadczenia Anny Wyki (1993). Zorientowałam się, że wysuwany tam postulat „obecności aktywnej” (tamże: 119120) świetnie współbrzmi z pomysłem „obserwacji przeżywanej”, proponowanym przez Radlińską (Radlińska 1937: 4). To były głosy stanowiące awers i rewers refleksji nad jakością obecności badacza - kogoś, kto uwrażliwia się na Innego (co doskonale pokazywała Radlińska), ale robi to poprzez wgląd w siebie samego; dopiero ów okrężny ruch od siebie do drugiego umożliwia bycie uważnym (to uwypukliła Wyka). O Hastrup dowiedziałam się z przywołanej pracy Wyki, gdzie szeroko opisywane są badania reprezentujące „ekstremalną” wersję przyglądania się sobie i własnemu doświadczeniu (Hastrup 1998). Taki pomysł badawczy, z mojego punktu widzenia, współgrał z istotą namysłu nad sobą w kontekście bycia świadomym siebie, $\mathrm{w}$ związku $\mathrm{z}$ rozbudzaniem $\mathrm{w}$ sobie nastawienia uważnej i uwrażliwionej obecności badacza.

MK: Wspomniałaś, że punktem wyjścia do zbudowania twojej bazy epistemologicznej była twórczość Radlińskiej, a czy pamiętasz, w jakich okolicznościach Radlińska zaczęła być dla ciebie znacząca? 
IKJ: Tutaj trzeba by się cofnąć do etapu moich studiów. Jako studentka pedagogiki społecznej często „ocierałam się” o figurę Radlińskiej. Wielokrotnie padało jej nazwisko podczas zajęć, niekiedy nawet miałam wrażenie, iż „jest jej pełno” i „nie mogę się od niej opędzić". Mimo to nie znalazłam wystarczających powodów, by wejść w relację z tekstami Radlińskiej, pozostały więc dla mnie niemymi (por. Witkowski 2009a: 406).

MK: Co o tym zadecydowało?

IKJ: Kilka czynników. Do kluczowych na pewno należał brak doświadczeń osobistych, które zachęciłyby mnie do obcowania z intelektualnym światem Radlińskiej. Ponadto, zbytnia jednowymiarowość w przedstawianiu nam - studentom - jej twórczości. Kursy, jakie przeszłam, ukształtowały we mnie zaledwie fragmentaryczne wyobrażenie o dyskursie Radlińskiej. Dodatkowo, pamiętam, że momentami przeszkadzał mi nazbyt apologetyczny ton, w jakim przedstawiano matkę założycielkę pedagogiki społecznej. Rodził on nieodparte skojarzenia z Gombrowiczowskim pastiszem zjawiska dogmatyzmu w przestrzeni kulturowej, co genialnie zostało zobrazowane w Ferdydurke: „... Słowacki wielkim poetą był!” (Gombrowicz 2007: 43). Z biegiem czasu, kiedy powoli krzepłam jako pracownik akademicki, Radlińska zaczęła mnie interesować pod innym kątem. Przygotowywałam się akurat do poprowadzenia ćwiczeń z pedagogiki społecznej i zwróciłam się do Profesor Ewy Marynowicz-Hetki z prośbą o użyczenie trudno dostępnej pozycji. Chodziło ni mniej, ni więcej tylko o Stosunek wychowawcy do środowiska społecznego! Pani Profesor we wcześniejszych naszych rozmowach napomknęła, że jeśli faktycznie chcę poznać Radlińską, to powinnam przeczytać tę właśnie książkę. I tak się stało, po czym... nastąpił przełom, lektura okazała się „wybuchowa” (Witkowski 2009b: 131-141). Natrafiwszy tam na fragmenty takie jak np.: „Idę w zamyśleniu nad dostrzeganym obrazem. Gdy się już we mnie odbił, gdy stał się moją własnością - szukam w dotychczasowej wiedzy o tutejszych stosunkach wyjaśnień, dlaczego tak jest. Zadaję sobie pytanie, jak być powinno..." (Radlińska 1935: 78), przecierałam oczy ze zdumienia. Trudno mi było uwierzyć, że podobne ustępy wyszły spod pióra autorki, którą znałam wyłącznie jako „twardą pozytywistkę”. Rozstrzygający dowód na to, że widziałam Radlińską w krzywym zwierciadle stanowił artykuł Wiesława Theissa pt. Heleny Radlińskiej koncepcja badania i działania (1994/1995), gdzie explicite mowa jest o dwóch komplementarnych liniach jej twórczości „pozytywistycznej” i „antypozytywistycznej” (tamże: 18).

MK: Słuchając ciebie, Izo, zacząłem zastanawiać się nad moją drogą odkrywania Radlińskiej...

IKJ: Bardzo jestem ciekawa twoich doświadczeń...

MK: Pozwolisz, że, tak jak ty, pokuszę się o ekskursję pamięciową. Zacznę od wątku na pozór tylko pobocznego. Otóż, do środowiska pedagogów przynależę od skrom- 
nych ośmiu lat. Formalnie, od października 2008 r., kiedy to rozpocząłem pracę w Katedrze Badań Edukacyjnych Uniwersytetu Łódzkiego. Wcześniej byłem związany z etnologami z Instytutu Etnologii i Antropologii Kulturowej naszego Uniwersytetu, gdzie przygotowywałem doktorat ${ }^{11}$. Wywołuję swój etnologiczny background nie bez powodu. Skłonny jestem przyjąć, iż to on decydował o charakterze moich pierwszych zetknięć z Radlińską, i to on przesądził finalnie też o tym, że doszło do spotkania „Izabeli Kamińskiej-Jatczak” z „Marcinem Kafarem”. Nie wybiegajmy jednak zbyt daleko w przyszłość.

Mówiłaś o „figurze Radlińskiej” i o niemożności „opędzenia się od niej”. Twoje wrażenie nie jest odosobnione. Jako etnolog - obcy wkraczający do świata pedagogów, doświadczyłem bliźniaczego stanu.

Radlińska istnieje na Wydziale Nauk o Wychowaniu co najmniej dwuwymiarowo: tekstualnie i werbalnie. Słyszałem o niej wielokrotnie np. podczas naukowych zebrań, odbywających się co miesiąc w Katedrze Badań Edukacyjnych. Sprzyjały one zorientowaniu się, że - à propos twoich skojarzeń Gombrowiczowskich - rdzenni łódzcy pedagodzy wyjątkowo chętnie przywołują dwa nazwiska na okoliczność budowania swojego zaplecza argumentacyjnego, a mianowicie Kamińskiego i... Radlińską. „Kim są «Kamiński» i «Radlińska»?”, zastanawiałem się, uznając w pierwszym rzucie, iż sprawa dotyczy badaczy silniej niż inni decydujących o kolorycie „lokalnego paradygmatu”12 pedagogicznego. Odezwał się we mnie syndrom typowego nowicjusza. Skutkował on m.in. tym, że starałem się wyleczyć z braków kompetencyjnych, podejmując na własną rękę poszukiwania biblioteczne i internetowe mające mi pomóc, jak zakładałem, w bliższym rozeznaniu się w sytuacji, w jakiej się znalazłem ${ }^{13}$.

IKJ: A co z Radlińską?

MK: Wobec Radlińskiej pozostawałem „nienachalny”, podobny stosunek miałem zresztą do Kamińskiego. Długo (mowa o latach, nie miesiącach) pozwalałem moim Koleżankom i Kolegom na stopniowe uwrażliwianie mnie na te nazwiska i idee z nimi kojarzone. Jednakowoż - co trzeba podkreślić - działo się to mimowolnie. Włączani w konteksty małych dramatów społecznych (np. kuluarowych rozmów) Kamiński oraz Radlińska, przede wszystkim Radlińska, stawali się centralnymi punktami odniesień. Ich duch przenikał do dysput intelektualnych, których byłem świadkiem i uczestnikiem. Niejednokrotnie bywali też bohaterami opowieści

\footnotetext{
11 Dysertację pt. Ja, Antropolog - Ja, Człowiek. O pewnym wariancie antropologii zaangażowanej broniłem wiosną 2009 r., kilka miesięcy po podjęciu zatrudnienia na Wydziale Nauk o Wychowaniu UŁ.

12 Termin „lokalny paradygmat” zaczerpnąłem z nomenklatury Andrzeja P. Wejlanda (2004).

${ }^{13} \mathrm{Na}$ marginesie dodam, że poszukiwania te, w istocie stosunkowo pobieżne, zaowocowały ciekawym odkryciem, takim mianowicie, iż Kamiński ma na imię Aleksander i jest autorem Kamieni na szaniec. Powieść tę czytałem, będąc jeszcze w szkole podstawowej i muszę przyznać, że pozostaje ona w wielkim intelektualnym kontraście z uznawanym na naszym Wydziale za klasyczny tekstem tego samego autora pt. Metoda, technika, procedura badawcza w pedagogice empirycznej (1974) - artykułem, z którym notabene musiałem się gruntownie zapoznać, wstępując na ścieżkę dydaktyki pedagogicznej.
} 
o tożsamościowych identyfikacjach (albo ich braku). Dla mnie opowieści te, z jasnych względów, zyskiwały ambiwalentną wymowę.

IKJ: Wyjaśnij proszę, dlaczego tak się działo?

MK: Czy mi się to podobało, czy nie, rozpoczęcie pracy w Katedrze Badań Edukacyjnych oznaczało zgodę na przeformułowanie, rozluźnienie, a nawet zerwanie więzów scalających mnie ze środowiskiem etnologów. Wiele okoliczności (to temat aż nazbyt rozległy) potwierdziło, że taki proces rzeczywiście zachodził. Mam na myśli coraz większe oddalanie się od świata etnologicznego i zbliżanie do świata pedagogicznego (obu rozumianych środowiskowo, instytucjonalnie, jak też myślowo). Nazwałem siebie „obcym” pośród pedagogów, ale równie dobrze powinienem się uzbroić w tę samą etykietkę, wracając dziś - oczywiście hipotetycznie - na grunt etnologiczny. Moja świadomość jest naznaczona wyraźnym piętnem „obcego”, nic na to nie poradzę.

IKJ: Wartościujesz to?

MK: Nie. Po prostu, traktuję ten stan jako „normalny” przy całym jego niewątpliwym zagmatwaniu. Choć nie było to łatwe, nauczyłem się ześrodkowywać bardziej na tkwiącej w nim sile twórczej aniżeli kłopotach z niego wynikających.

IKJ: Wykazujesz się niestandardowym podejściem, Marcinie.

MK: Raczej pragmatycznym. [śmiech]

Skoro już jesteśmy przy „siłach twórczych” przynależnych stanom pośrednim, międzydyscyplinarnym, chciałbym opowiedzieć ci teraz o zdarzeniu, które takie siły uruchomiło. Jednocześnie proponuję, abyśmy tę historię potraktowali jako przemieszczającą nas na kolejny poziom dyskusji.

IKJ: Zamieniam się w słuch.

MK: W 2011 r. opublikowałem artykuł zatytułowany $O$ współuczestnictwie i osobistym ethosie $w$ kontekście Społeczności wiejskiej Kazimiery Zawistowicz-Adamskiej (Kafar 2011b). Jakież było moje zdziwienie, gdy po zapoznaniu się z nim, mój szef, Profesor Jacek Piekarski, zaczął roztaczać wizję badań nad wsią. Zgodnie z wyobrażeniami Profesora, mogłyby one być poprowadzone wspólnie przez naszą Katedrę oraz Instytut Etnologii i Antropologii Kulturowej UŁ. „Świetny plan - pomyślałem tylko czy faktycznie dla mnie? Nie interesuję się wsią w sensie ściśle badawczym, ba - właściwie nigdy się nią nie zajmowałem, wyłączając parę błahych poznawczo epizodów. Jaką więc rolę miałbym pełnić w tym projekcie, gdyby doszedł on do skutku?" - zastanawiałem się. W tekście $O$ współuczestnictwie i osobistym ethosie... skupiałem się na motywie terenowych aktywności badawczych. Co się dzieje z prowadzącym badania, gdy pokonuje kolejne progi zażyłości, niekiedy nawet intymności w relacjach z osobami spotykanymi na swej drodze? Czy uprawiając etnografię/antropologię, przestajemy być ludźmi z krwi i kości? Takie m.in. pytania 
stawiała Zawistowicz-Adamska w Społeczności wiejskiej, ściślej: ja te pytania odnajdowałem w jej książce i miałem po temu konkretny powód, ale o nim opowiem później. Znamienne jest to, że, jak mi się wydawało, Jacek Piekarski nie podążył wówczas wskazanym przeze mnie tropem, dlaczego? Otóż, sądziłem, iż czytał moją pracę przez pryzmat problemów przynależnych rodzimej mu pedagogice społecznej, moje problemy mieściły się zaś w polu metodologii współczesnej antropologii, tzn. ja je tam sytuowałem.

IKJ: Krótko mówiąc - rozmijaliście się z Profesorem...

MK: Owszem, rozmijaliśmy, ale... chyba nie do końca. Żyjąc z podzieloną świadomością, pozostajesz w dwójnasób czujnym i ja się tą czujnością wykazałem, kodując następujące zdanie wypowiedziane przez Profesora, zacytuję je z pamięci: „Badania na wsi robiła m.in. Helena Radlińska...”. Zdanie to, będę szczery, nie przedstawiało nadzwyczajnej wartości aż do chwili, kiedy to przesłałaś mi swój artykuł, ten, od którego zaczęliśmy naszą rozmowę.

IKJ: Przyznaję, że jestem zaskoczona i zaintrygowana zarazem. Co łączy stwierdzenie o badaniach uskutecznianych przez Radlińską na wsi z moim artykułem?

MK: Dla postronnego czytelnika najprawdopodobniej niewiele, dla mnie - wprost przeciwnie! Twój tekst uruchomił u mnie kaskadę skojarzeń, które - poparte kolejnymi śladami tekstualnymi i pozatekstualnymi, na jakie trafiałem - zadziałały niczym twórczy spust. Jest w Refleksjach z pola praktyki pewien cytat tłumaczący, czym jest „wżycie się” w środowisko...

IKJ: ...mówisz o cytacie ze Stosunku wychowawcy do środowiska społecznego...

MK: Tak. Wedle tego cytatu, „wżyć się” w środowisko oznacza „poznać nie tylko warunki zewnętrzne jego bytu, lecz również pojęcia i pragnienia w niem żyjące, istotę mocy duchowej i więzy, które je łączą ze światem" (Radlińska 1935: 75, za: Kamińska 2016: 258; zapis zgodny z oryginałem). Czytając ten ustęp doznałem olśnienia. „Przecież to jest język bardzo dobrze mi znany. To jest język Kazimiery Zawistowicz-Adamskiej!” - wykrzyknąłem. Żeby nie być gołosłownym. W Społeczności wiejskiej natrafiamy np. na takie choćby passusy:

Trzeba żyć nie tylko wśród nich, ale z nimi, by dotrzeć do surowej prawdy ich życia. Stąd jeszcze dalej idący wniosek: trzeba odrzucić precz własny świat nawyków, pojęć, reakcji. Nie mierzyć własną miarą tych ludzi „z innego świata”. Zżyć się z nimi tak, by przejąć ich miarę pojmowania otaczających zjawisk. Wydaje się to na pozór trudne, ale tylko na pozór. Bo taką umiejętność wrośnięcia w środowisko zdobywa się z dnia na dzień wraz z postępem badań, które polegają nie na suchym rejestrowaniu dostrzeżonych zjawisk, ale na ich przeżywaniu. Aż staną się namacalne, żywe, pulsujące żywą krwią. I zrozumiałe (Zawistowicz-Adamska 1948: 128). 
Albo też:

W gromadzie wiejskiej, gdzie jedni o drugich wiedzą wszystko, nowy przybysz tym więcej uważany jest za kogoś obcego, im mniej o nim wiadomo. Życzliwe zainteresowanie się jego życiem osobistym jest jednym z czynników zacierających poczucie obcości. On tymczasem w miarę wrastania w nowe środowisko, mniej czy więcej świadomie zatraca własny świat, żyjąc nowymi wrażeniami, nowymi wzruszeniami, wyrabiając nowy pogląd na zawiłości ludzkiego istnienia. O bogactwie czy zubożeniu tak odmienionego własnego świata rozstrzygnie ciężar gatunkowy doznanych przeżyć, jak o wrośnięciu w środowisko rozstrzygać będzie malejące z dnia na dzień poczucie obcości i osamotnienia (tamże: 134).

IKJ: Marcinie, moim zdaniem doszliśmy do punktu, w którym doskonale widać, jak doświadczenia teraźniejsze zaplatają się z doświadczeniami przeszłymi. Co więcej, nie są to tylko doświadczenia nasze - twoje i moje, to są także doświadczenia Radlińskiej i Zawistowicz-Adamskiej...

MK: Przypuszczam, że wychwycenie językowej bliskości to zaledwie wierzchołek góry lodowej...

IKJ: Wiele na to wskazuje. Pamiętasz może, jak powiedziałam ci kiedyś, że czytając Oświatę i kulturę wsi polskiej (Radlińska 1979), w pewnym momencie natrafiłam na ustęp zatytułowany Twórcza siła tradycji na wsi (tamże: 219-220)?

MK: Pamiętam.

IKJ: Drążyłam temat i okazało się, że był tam też przypis mówiący o tym, iż jest to przedruk fragmentu słowa wstępnego autorstwa Radlińskiej (nosił on tytuł Od Wydawców), które rozpoczynało książkę Kazimiery Zawistowicz-Adamskiej pt. Żywe tradycje współdziałania na wsi (1948). Ponieważ w książce Radlińskiej (1979) znajdował się tekst niepełny, sięgnęłam do oryginału. Posłuchaj, co tam znalazłam:

Współpraca nauk badających drogi przemian z etnografią zaczęła się przed wojną. Przodowniczką była praca dr Kazimiery Zawistowicz „Problem kultury ludowej w badaniach nad środowiskiem” (1938). W czasie wojny, w tragicznie przerwanym kształceniu pracowników kulturalnych dla ziem postulowanych, ściśle współpracowały w Wolnej Wszechnicy Polskiej katedry etnografii i pedagogiki społecznej (Radlińska 1948: 4).

MK: Przywołany przez ciebie cytat jest niezwykły, świadczy zarówno o bezpośrednich związkach Radlińskiej z Zawistowicz-Adamską, jak i korelacjach rodzimych nam dyscyplin - etnografii i pedagogiki społecznej w wydaniu okołowojennym.

IKJ: Otóż to!

MK: Na te związki - choć pośrednio - wskazuje też Małgorzata Golicka-Jabłońska (2011: 19), pisząca o zaangażowaniu obu: Zawistowicz-Adamskiej i Radlińskiej w tajne nauczanie: 
[Kazimiera Zawistowicz-Adamska] [w]ykładała etnografię na kompletach Wolnej Wszechnicy. Wykłady odbywały się w prywatnych mieszkaniach i w klasztorze sióstr Urszulanek Szarych SJK przy ulicy Gęstej w Warszawie. Za murami klasztoru zakonnice organizowały życie intelektualne i ukrywały poszukiwanych przez gestapo. U sióstr mieszkała profesor Helena Radlińska i ksiądz Jan Zieja - oboje bardzo prężni w konspiracyjnej działalności oświatowej (tamże).

IKJ: Wygląda na to, że dostrzeżona przez nas wspólnota języka pokrywa się ze wspólnotą doświadczeń życiowych, tam właśnie ma pierwotne ukorzenienie. Przyznasz, Marcinie - to frapujący trop, zachęcający do dalszych poszukiwań źródłowych...

MK: Zgadzam się z tobą, Izo. Stopniowo docieramy do warstwy, którą chętnie nazwałbym obcowaniem $z$ dziedzictwem. Wchodzimy w przestrzeń, gdzie niesie się echo międzygeneracyjnych zależności...

IKJ: Chyba warto, żebyś wobec tego powiedział, co zawiodło cię do Zawistowicz-Adamskiej?

MK: Odpowiadając na twoje pytanie wprost - odczuwanie braku, niedostatku w obrębie narzędzi poznawczych, jakimi dysponowała antropologia w wydaniu lokalnym, polskim przełomu XX i XXI w. U Zawistowicz-Adamskiej znalazłem to, czego nie mogli mi zaoferować inni, w tym sensie jest ona moim wielkim odkryciem. Co ciekawe, to odkrycie raczej nie ujrzałoby światła dziennego, gdyby nie swoista otoczka intelektualna sprzyjająca jego wybrzmieniu. W czym rzecz? Cofnijmy się do lat 90. XX w. W 1992 r. zaczynałem studia etnologiczne na Uniwersytecie Łódzkim. To był okres wielkiej wojny paradygmatów w polskiej nauce o kulturze. „Etnografia w starym stylu”, jak mieliśmy wtedy w zwyczaju mówić, zderzała się z „antropologią kulturową", przy czym etnografia, stereotypowo kojarzona z kulturą wsi polskiej i jej deskrypcjami jeden do jednego (np. jak wyglądało radło przed pięćdziesięciu laty w Małopolsce), pozostawała w odwrocie, zaś mająca teoretyczne zakusy antropologia była na fali wznoszącej. Uwierz, że zdecydowanie bardziej nobilitujące było przyznać się, iż należysz do frakcji antropologicznej, a nie etnograficznej.

IKJ: A ty przyznawałeś się do...

MK: Oczywiście aspirowałem do tej pierwszej - jakże by inaczej! [śmiech] Kontynuując główny wątek. Ów podział paradygmatyczny ujawniał się na wielu poziomach, m.in. uzewnętrzniała go dydaktyka. Program studiów świetnie odzwierciedlał wpływy poszczególnych klanów. Część zajęć miała charakter czysto etnograficzny, inne szły po linii antropologicznej. Nie dziwi zatem, że, dla przykładu, „antropolodzy” jak ognia unikali przedmiotów „etnograficznych”, i na odwrót. Udział w zajęciach z, dajmy na to, Metodyki badań terenowych, gdzie dowiadywaliśmy się, że współczesny etnograf używa magnetofonu szpulowego jako nowoczesnego 
narzędzia do robienia wywiadów, wzbudzał w nas nierzadko poirytowanie i sporą niechęć. Kłopot polegał na tym, że krok po kroku my-antropolodzy wyrabialiśmy sobie ogólny stosunek negatywny do wszystkiego, co dotyczyło ich-etnografów. Wspomniałem o Metodyce badań terenowych, gdyż to właśnie w treściach tego przedmiotu pojawiła się Społeczność wiejska. Tyle tylko, że była traktowana nad wyraz instrumentalnie, stanowiła swego rodzaju instrukcję dla studentów mających wyruszyć wkrótce po raz pierwszy w teren. Taki, a nie inny klimat sprawił, iż przywoływana książka przemknęła przez nasze głowy niczym kot przez jezdnię. Ot, po prostu jedna z wielu lektur do przerobienia i... zapomnienia. W moim przypadku rozbrat ze Społecznościq wiejskq trwał ponad dziesięć lat.

IJK: To długo czy krótko?

MK: Na pewno wystarczająco długo, aby zyskać dystans niezbędny do trzeźwej oceny sytuacji. Powróciłem do etnograficznych źródeł niczym syn marnotrawny w drugiej połowie lat 2000. Metafora „syna marnotrawnego” jest tutaj bardzo na miejscu, gdyż do etnografii szedłem drogą okrężną - antropologiczną.

IKJ: Jak to się stało?

MK: Jak napomknąłem w początkowych partiach naszej rozmowy, w 2004 r. trafiłem do Domu Pomocy Społecznej, gdzie prowadziłem badania terenowe. Tuż po ich rozpoczęciu zdałem sobie sprawę, że po uszy jestem pogrążony w kryzysie poznawczym...

IKJ: Chodziło o trudności w godzeniu roli badacza i opiekuna osób chorych?

MK: Tak. Mimo usilnych starań, nie byłem w stanie wyzwolić się - ujmę to patetycznie - z pęt własnego człowieczeństwa. Kiedy wydawało mi się, że na dobre „zakleszczyłem się” między dwoma skrajnie odmiennymi postawami: „naturalnym” egzystencjalnie współczuciem a uprawianiem nauki, znalazłem niespodziewanego sprzymierzeńca w osobie Kazimiery Zawistowicz-Adamskiej, która wsparła mnie wyprzedzającą swą epokę - Społecznościq wiejskq.

Dwa słowa o perypetiach, jakie przechodziła ta praca. Otóż, wydawana była dwukrotnie, wpierw w 1948 r. przez Polski Instytut Służby Społecznej jako Społeczność wiejska. Doświadczenia i rozważania z badań terenowych $w$ Zaborowie, a następnie w roku 1958 przez Ludową Spółdzielnię Wydawniczą jako Społeczność wiejska. Wspomnienia i materiały z badań terenowych: Zaborów 1937-1938 (Wydanie 2. przejrz. i uzup.). Wydanie 1., to z 1948 r., do tego stopnia nie zyskało aprobaty ze strony ówczesnej władzy, iż wstrzymano jego dystrybucję. I oto znowu mamy do czynienia z paradoksem. Nie umiem powiedzieć, co dokładnie działo się przedtem, natomiast w połowie lat 1990. ta książka traktowana była na równi z makulaturą. Kilkaset woluminów wybitnego dzieła pozostawało poza katalogiem, ułożono je w niedbały stos na zapleczu biblioteki mieszczącej się przy ul. Jaracza 78 w Łodzi. Studenci, w tym i ja, mieli przyzwolenie na pobieranie stamtąd dowolnej ilości 
egzemplarzy Społeczności wiejskiej, tyle tylko, że mało kto w praktyce korzystał z tej okazji. Ja zaopatrzyłem się w kilka sztuk, ale - przyznaję - bynajmniej nie zrobiłem tego z pędu do wiedzy, raczej z zakusów kolekcjonerskich. Mówiąc wprost, przeniosłem, jak się potem okazało, najważniejszą dla mnie publikację Profesor Zawistowicz-Adamskiej z szarej sfery pamięci dyscyplinarno-instytucjonalnej w szarą sferę pamięci prywatnej, domowej - Społeczność wiejska trafiła bowiem na górne półki regału z literaturą, po którą nie sięgałem w ogóle lub tylko okazjonalnie.

Kto wie, jak potoczyłyby się moje naukowe losy, gdyby, skromne 10 lat później, nie skontaktował się ze mną kolega robiący w tamtym czasie badania terenowe w wiosce położonej blisko Zaborowa. Tym kolegą był Robert Dzięcielski, naonczas adiunkt w Instytucie Etnologii i Antropologii UŁ. Znaliśmy się i rozumieliśmy na tyle dobrze, że postanowiłem podzielić się z nim materiałami z badań w Domu Pomocy Społecznej. Robert, po zapoznaniu się z moimi notatkami, zapytał, czy znam Społeczność wiejskq̨; przy okazji zauważył, że istnieje uderzające podobieństwo między sposobem pisania uskutecznianym przez Kazimierę Zawistowicz-Adamską a moim. Sprawdziłem. Profesor nie dość, że pisała w stylu, który faktycznie okazał się zbliżony do mojego, to pisała o sprawach dla mnie fundamentalnych - o człowieku (w tym także etnografie jako człowieku), relacjach międzyludzkich, spotkaniu terenowym jako dramacie rozgrywającym się między nią a Innym. Pisała wreszcie o wielkiej sile „wyrozumienia” (to bodaj najpiękniejsze słowo pojawiające się na kartach Społeczności wiejskiej) i przyjaźni, którą traktowała jako - a i owszem - równoprawną z innymi kategorię epistemologiczną. Czytałem, czytałem i czytałem, z każdym kolejnym akapitem utwierdzając się w przekonaniu, że wreszcie jestem w (intelektualnym) domu.

IKJ: Ta opowieść daje do myślenia... Sposób, w jaki traktowano Społeczność wiejskq w czasie, gdy studiowałeś... Twoje wspomnienia, Marcinie, pokazują szerszy problem, a mianowicie wpływ cenzorskich zapędów władz komunistycznych, ograniczających wolność naukowej wypowiedzi na dalsze losy „blokowanych” dzieł. Patrząc pod tym kątem, warto, jak sądzę, ponownie rozważyć kwestię możliwości wykorzystania w pełnym zakresie dorobku Radlińskiej. Dziękuję, że zwróciłeś mi na to uwagę. Szczególnie, że, jak wiadomo z dziejów Katedry Pedagogiki Społecznej na Uniwersytecie Łódzkim, przeżywała ona okres swojego niebytu w latach 50. XX w. Odradzała się ponownie pod koniec roku 1961 pod kierownictwem Aleksandra Kamińskiego, ale działo się to już w „nowej” pedagogicznej rzeczywistości. Barbara Smolińska-Theiss napisała, że była to rzeczywistość, w której „pedagogika społeczna jako dyscyplina i praktyka straciła swoje wcześniejsze korzenie. Dorobek Heleny Radlińskiej znalazł się na indeksie" (Smolińska-Theiss 2015: 43). Nie zastanawiałam się wcześniej nad tym, czemu tak istotna dla mnie książka, jaką jest Stosunek wychowawcy do środowiska społecznego, nigdy nie była wznawiana... Zresztą do tej pory jest dość wąsko dostępna - np. biblioteka uniwersytecka w Łodzi posiada jeden egzemplarz tej pozycji... 
Wracając do ciebie i Zawistowicz-Adamskiej, ty jednak ponownie sięgnąłeś po Społeczność wiejska, otrzepałeś ją z kurzu...

MK: Zgadza się, to był początek wspaniałej, ogromnie kształcącej, formującej mnie wielowymiarowo („profesjonalnie” i „nieprofesjonalnie” (Kafar 2013a, 2011a)) przygody, ale proponuję, abyśmy o niej podyskutowali szerzej już przy innej okazji. W zamian pokuszę się o poczynienie paru syntetyzujących uwag puentujących to, o czym dziś rozmawialiśmy.

Okazuje się więc, Izo, że istnieje w Polsce „pole różnic i podobieństw” między pedagogiką społeczną a etnografią/antropologią, zaś jego elementy składowe ujawniają się m.in. poprzez stosunek przedstawicieli obu dyscyplin do własnej przeszłości indywidualnej i wspólnotowej ${ }^{14}$. Przejścia od etnografii do antropologii, od antropologii do etnografii, swego rodzaju hybrydalność, czy nawet symbioza etnograficzno-antropologiczna, $\mathrm{z}$ jaką mamy obecnie do czynienia, bezspornie stanowią wyróżnik polskiego wariantu nauk o człowieku. Moja „działaniowo-intelektualna przygoda” z Kazimierą Zawistowicz-Adamską w roli głównej uzmysłowiła mi, że owa symbioza, swoisty mariaż tego, co teraźniejsze, z tym, co przeszłe, przy umiejętnym podejściu do wartości cechujących te perspektywy, sprzyja natrafieniu na inspirujące możliwości badawcze, krótko mówiąc - odpoznana przeszłość stanowi cenny budulec prospektywny ${ }^{15}$.

I jeszcze jedno. Kiedy odkryłem dziedzictwo Kazimiery Zawistowicz-Adamskiej, byłem przekonany, że taki „szczęśliwy traf” już się więcej nie powtórzy. (Jakie jest prawdopodobieństwo wystąpienia tożsamej koincydencji?) Na szczęście myliłem się. Dzięki naszemu spotkaniu właśnie przeżywam déjà vu. Tym razem chodzi o odkrywanie dziedzictwa Heleny Radlińskiej za pośrednictwem dziedzictwa Zawistowicz-Adamskiej. Na tym polega jego właściwość, na podwojeniu. Niewątpliwie, wyłania się tu szczególny „łańcuch spraw i ludzi”, jak powiedziałaby uczennica Radlińskiej, Irena Lepalczyk (2003: 318). Czuję się jednym z jego (zagubionych?) ogniw i niezmiernie cieszę się, że oto ponownie, poprzez uruchomienie podmiotowego wymiaru praktyki naukowej, dokonuje się symboliczne scalenie światów - pedagogiki i etnografii - których drogi dawno, dawno temu się rozeszły...

\footnotetext{
14 Wypada się zastanowić, czy obserwowane wychylenie ku przeszłości, znamionujące pedagogikę społeczną ogranicza się tylko do niej. „Pogotowie myślowe” (Fleck [1935] 2007b: 116) o podobnej aurze ujawniło się w etnografii/antropologii (domagającej się ponowienia dyskusji nad, nomen omen, „szkołą etnograficzną Kazimiery Zawistowicz-Adamskiej” (Nadolska-Styczyńska 2011: 7)), jak i socjologii, gdzie z kolei przedstawicielki trzeciego pokolenia łódzkiej szkoły metodologicznej (sic!) wystąpiły z pomysłem „przygotowania biografii [tejże] szkoły”, wynikającym z „potrzeby zrozumienia i «przepracowania» dziedzictwa, dotychczasowego niepełnego pojęcia szkoły, odkrycia go także dla siebie" (Grzeszkiewicz-Radulska, Krzewińska 2015: 30; por. też Kafar 2016b: 230-231). Czy to zwykły zbieg okoliczności, że w każdym z przywołanych przypadków sprawa dotyczy lokalnego, łódzkiego środowiska naukowego? $15 \mathrm{U}$ mnie walnie przyczynił się on do stworzenia projektu antropologii zaangażowanej, który w płaszczyźnie formalno-instytucjonalnej - zaowocował doktoratem, cyklem artykułów (Kafar 2010a, 2010b, 2010c, 2007) i książką (Kafar 2013b).
} 
IKJ: Mnie też sprawia to radość. Nasze rozpoznania dobitnie przekonują, że „wstępy" pedagogiki społecznej (zawsze łączyłam je wyłącznie z osobą Heleny Radlińskiej) dotyczą także etnografii ucieleśnianej przez Kazimierę Zawistowicz-Adamską. Sama Radlińska przyznawała przecież:

Prace kierowane przez Kazimierę Zawistowicz-Adamską, wprowadzają badania ludoznawcze na nowe drogi, przy czym wiązanie etnografii z badaniami środowisk z punktu widzenia służby społecznej nie tylko zwraca uwagę na niedostrzegane dotychczas fakty i zjawiska, lecz również oświetla drogi działalności, zmierzającej do uruchamiania sił społecznych w celach przebudowy (Radlińska 1979: 220).

Instruktywną jest też pod tym względem przedmowa do Społeczności wiejskiej16, w której Radlińska zwraca uwagę na to, że autorka dzieli się swoimi przeżyciami związanymi z procesem wrastania w środowisko badanych:

Dr Kazimiera Zawistowicz wrosła w zaborowską glebę. Jak się to stało mówi sama, mówią też zaborowianie (...) Niezależnie od ścisłego opracowania wyników badań, wyłonił się z przeżyć badaczki obraz Zaborowa, przekraczający schematy kwestionariuszy, skupiający w artystycznym ujęciu prawdę o biedzie i mocy, o pięknie i obyczaju, o przeszłości i dążeniach wsi (Radlińska 1958: 14).

Celowo, na koniec, przytoczyłam fragmenty wypowiedzi Radlińskiej o Zawistowicz-Adamskiej, ponieważ pod wpływem rozmowy z tobą, Marcinie, widzę ich rosnącą wagę i znaczenie. Radlińska staje się dla mnie drogowskazem do studiowania Społeczności wiejskiej. Także i w tym sensie moje doświadczenie zaczynam traktować jako odbite w lustrze twoich doświadczeń.

MK: Potraktujmy to, co powiedziałaś, Izo, za domknięcie dzisiejszej rozmowy. Serdecznie ci za nią dziękuję.

IKJ: Ja też ci dziękuję, i do zobaczenia.

MK: Do zobaczenia.

\section{Bibliografia}

Bohuszewicz P., Markiewka T. S. (2014) Autor: empiryczny, modelowy czy wirtualny, „Przestrzenie Teorii”, t. 22, s. 191-205.

Bourdieu P., Wacquant L. J. D. (2001) Zaproszenie do socjologii refleksyjnej, tłum. A. Sawisz, Warszawa, Oficyna Naukowa.

\footnotetext{
16 Fragment pochodzi z przedmowy do wydania 1. Społeczności wiejskiej (1948), którą opracowała Helena Radlińska, o czym można się dowiedzieć z przypisu do przedruku znajdującego się w wydaniu 2. (Zawistowicz-Adamska 1958). Oryginał był podpisany bezimiennie przez Polski Instytut Służby Społecznej.
} 
Fleck L. (1986) Powstanie i rozwój faktu naukowego. Wprowadzenie do nauki o stylu myślowym i kolektywie myślowym, tłum. M. Tuszkiewicz, Wydawnictwo Lubelskie.

Fleck L. ([1938] 2007a) Problemy naukoznawstwa w: L. Fleck, Style myślowe i fakty. Artykuły i świadectwa, S. Werner, C. Zittl, F. Schmaltz (red.), Warszawa, Wydawnictwo IFiS PAN, s. 148-162.

Fleck L. ([1935] 2007b) O obserwacji naukowej i postrzeganiu wogóle w: L. Fleck, Style myślowe i fakty. Artykuły i świadectwa, S. Werner, C. Zittl, F. Schmaltz (red.), Warszawa, IFiS PAN, s. 113-132.

Foucault M. (1977) Archeologia wiedzy, tłum. A. Siemek, Warszawa, Państwowy Instytut Wydawniczy.

Golicka-Jabłońska M. (2011) Szkic do portretu prof. dr Kazimiery Zawistowicz-Adamskiej w: Wokót społeczności wiejskiej. Etnografia Kazimiery Zawistowicz-Adamskiej - kontynuacje i inspiracje, G. E. Karpińska, A. Nadolska-Styczyńska (red.), Wrocław-Łódź, Polskie Towarzystwo Ludoznawcze, s. 15-31.

Gombrowicz W. (2007) Ferdydurke. Lekcja literatury z Jerzym Jarzębskim i Andrzejem Zawadzkim, Kraków, Wydawnictwo Literackie.

Grzeszkiewicz-Radulska K., Krzewińska A. (2015) O tym, jak pisać biografię naukowq (łódzka szkoła metodologiczna), „Przegląd Socjologiczny”, t. 64, nr 4, s. 27-49.

Hastrup K. (1998) Poza antropologia. Antropolog jako przedmiot przedstawienia dramatycznego, tłum. G. Godlewski, „Polska Sztuka Ludowa. Konteksty. Antropologia kultury. Etnografia. Sztuka", nr 2, s. 20-28.

Kamińska I. (2016) O (nie)udanej próbie odnalezienia się $w$ roli praktykującego badacza. Refleksje z pola praktyki w: Auto/biograficzne aspekty praktyk poznawczych, M. Kafar (red.), Łódź, Wydawnictwo Uniwersytetu Łódzkiego, s. 255-269.

Kamiński A. (1974) Metoda, technika, procedura badawcza w pedagogice empirycznej w: Metodologia pedagogiki społecznej, T. Pilch, R. Wroczyński (red.), WrocławWarszawa-Kraków-Gdańsk, Ossolineum, s. 25-48.

Kafar M. (2007) Projekt „etnografii doświadczenia” Kazimiery Zawistowicz-Adamskiej i jego współczesne zastosowania, „Lud”, t. 91, s. 111-135.

Kafar M. (2010a) O idei verbum interius i formie bardziej pojemnej w opisie antropologicznym w: Wykluczanie. Społeczno-kulturowe mechanizmy kreowania emocji, B. Płonka-Syroka, K. Marchel (red.), Wrocław, Oficyna Wydawnicza Arboretum, s. 249-282. 
Kafar M. (2010b) Zwroty zapoznane - zwroty dokonane. Autobiografia w myśleniu etnograficznym i antropologicznym w: „Zwroty” badawcze w humanistyce. Konteksty poznawcze, kulturowe i społeczno-instytucjonalne, J. Kowalewski, W. Piasek (red.), Olsztyn, Instytut Filozofii Uniwersytetu Warmińsko-Mazurskiego w Olsztynie, s. 211235.

Kafar M. (2010c) O współuczestnictwie i osobistym ethosie $w$ kontekście Społeczności wiejskiej Kazimiery Zawistowicz-Adamskiej w: Wokół społeczności wiejskiej. Etnografia Kazimiery Zawistowicz-Adamskiej - kontynuacje i inspiracje, G. E. Karpińska, A. Nadolska-Styczyńska (red.), Wrocław-Łódź, Polskie Towarzystwo Ludoznawcze, s. $175-190$.

Kafar M. (red.) (2011a) Biografie naukowe. Perspektywa transdyscyplinarna, Łódź, Wydawnictwo Uniwersytetu Łódzkiego.

Kafar M. (2011b) O współuczestnictwie i osobistym ethosie $w$ kontekście Społeczności wiejskiej Kazimiery Zawistowicz-Adamskiej w: Wokół społeczności wiejskiej. Etnografia Kazimiery Zawistowicz-Adamskiej - kontynuacje i inspiracje, G. E. Karpińska, A. Nadolska-Styczyńska (red.), Wrocław-Łódź, Polskie Towarzystwo Ludoznawcze, s. $175-190$.

Kafar M. (red.) (2013a) Scientific biographies. Between the „professional” and "nonprofessional" dimensions of humanistic experiences, Łódź-Kraków, Wydawnictwo Uniwersytetu Łódzkiego, Wydawnictwo Uniwersytetu Jagiellońskiego.

Kafar M. (2013b) W świecie wygnańców, wdów i sierot. O pewnym wariancie antropologii zaangażowanej, Łódź, Wydawnictwo Uniwersytetu Łódzkiego.

Kafar M. (red.) (2016) Auto/biograficzne aspekty praktyk poznawczych, Łódź, Wydawnictwo Uniwersytetu Łódzkiego.

Kafar M., Ellis C. (2014) Autoethnography, storytelling, and life as lived. A conversation between Marcin Kafar and Carolyn Ellis, „Przegląd Socjologii Jakościowej/Qualitative Sociology Review", nr 3, s. 124-143.

Kafar M., Rydlewski M. (2016a) „Teksty mniejsze”, lecz nie pomniejsze. Wokół Czarnoksięstw humanistów. Część I, „Sensus Historiae”, t. 23, s. 153-172.

Kafar M., Rydlewski M. (2016b) „Teksty mniejsze”, lecz nie pomniejsze. Wokół Czarnoksięstw humanistów. Część II, „Sensus Historiae”, t. 24, s. 213-236.

Kafar M., Rydlewski M. (2016c) „Prawdziwe zmyślenie” - nieoczywiste pola znaczeń metafory literackiej w: Auto/biograficzne aspekty praktyk poznawczych, M. Kafar (red.), Łódź, Wydawnictwo Uniwersytetu Łódzkiego, s. 173-202. 
Kmita J. (1976) Szkice z teorii poznania naukowego, Warszawa, PWN.

Kmita J. (1985) Kultura i poznanie, Warszawa, PWN.

Kubinowski D. (2006) Pedagogiczne myślenie humanistyczne jako kategoria metodologiczna w: Metodologia pedagogiki zorientowanej humanistycznie, D. Kubinowski, M. Nowak (red.), Kraków, Oficyna Wydawnicza „Impuls”, s. 171-180.

Kubinowski D. (2010) Metodologia spod znaku $x^{2}$ a humanistyczna tożsamość pedagogiki w: Metodologiczne problemy tworzenia wiedzy w pedagogice, J. Piekarski, D. Urbaniak-Zając, K. J. Szmidt (red.), Kraków, Oficyna Wydawnicza „Impuls”, s. 79-99.

Kubinowski D. (2012) Rygor czy sztuka badań naukowych w pedagogice, „Rocznik Pedagogiczny", numer specjalny z okazji XXV-lecia LSMP pod patronatem KNP PAN pt. Dążenie do mistrzostwa..., M. Dudzikowa, R. Bery (red.), Radom, Instytut Technologii Eksploatacji - BIP, s. 123-140.

Kubinowski D. (2013) Rozwój badań jakościowych w pedagogice polskiej na przełomie XX i XXI wieku, Lublin, Wydawnictwo Makmed.

Lepalczyk I. (2003) Wśród ludzi i książek, Łódź, Wydawnictwo WiNG.

Marynowicz-Hetka E. (red.) (1997) Mistrz - uczeń: wyobrażenia czy rzeczywistość czyli o tworzeniu szkół naukowych, Łódź, Łódzkie Towarzystwo Naukowe.

Marynowicz-Hetka E. (2004) Pedagogika społeczna Aleksandra Kamińskiego - kilka uwag do tomu jubileuszowego z perspektywy długiego trwania w: Aleksander Kamiński i jego twórczość pedagogiczna: dyskusja o przeszłości wobec teraźniejszości i przyszłości, E. Marynowicz-Hetka, H. Kubicka, M. Granosik (red.), Łódź, Wydawnictwo Uniwersytetu Łódzkiego, s. 422-432.

Marynowicz-Hetka E. (2015) Przeszłość - teraźniejszość - przyszłość: zarys stanowiska społeczno-pedagogicznego w: Pedagogika społeczna: wstępy i kontynuacje, E. Marynowicz-Hetka, E. Skoczylas-Namielska (red.), Łódź, Wydawnictwo Uniwersytetu Łódzkiego, s. 15-25.

Marynowicz-Hetka E., Skoczylas-Namielska E. (red.) (2015a) Pedagogika społeczna. Wstępy i kontynuacje, Łódź, Wydawnictwo Uniwersytetu Łódzkiego.

Marynowicz-Hetka E., Skoczylas-Namielska E. (2015b) Przedmowa w: Pedagogika społeczna. Wstępy i kontynuacje, E. Marynowicz-Hetka, E. Skoczylas-Namielska (red.), Łódź, Wydawnictwo Uniwersytetu Łódzkiego, s. 7-13.

Marynowicz-Hetka E., Theiss W. (red.) (2004) Profesor Helena Radlińska: w sto dwudziestą piątą rocznicę urodzin i pięćdziesiątą rocznicę śmierci, Łódź, Łódzkie Towarzystwo Naukowe. 
Nadolska-Styczyńska A. (2011) Wprowadzenie w: Wokół społeczności wiejskiej. Etnografia Kazimiery Zawistowicz-Adamskiej - kontynuacje i inspiracje, G. E. Karpińska, A. Nadolska-Styczyńska (red.), Wrocław-Łódź, Polskie Towarzystwo Ludoznawcze, s. 7-11.

Namer E. (1985) Sprawa Galileusza, tłum. A. Galica, Warszawa, Oficyna Wydawnicza „Czytelnik”.

Nowak M. (2006) Metodologia pedagogiki między „naukowościa/teoretycznościq” a „praktycznościq" w: Metodologia pedagogiki zorientowanej humanistycznie, D. Kubinowski, M. Nowak (red.), Kraków, Oficyna Wydawnicza „Impuls”, s. 145-170.

Platon (1982) Dialogi, tłum. W. Witwicki, Warszawa, PWN.

Prokopiuk W. (2006) Wprowadzenie do rozważań nad humanizacja pedagogiki (edukacji) w kontekście filozoficznych aspektów przestrzeni pedagogicznej przełomu wieków w: Metodologia pedagogiki zorientowanej humanistycznie, D. Kubinowski, M. Nowak (red.), Kraków, Oficyna Wydawnicza „Impuls”, s. 127-144.

Radlińska H. (1935) Stosunek wychowawcy do środowiska społecznego. Szkice z pedagogiki społecznej, Warszawa, „Nasza Księgarnia” Sp. Akc. Związku Nauczycielstwa Polskiego.

Radlińska H. (1937) Uwagi o metodzie przeprowadzanych badań w: Społeczne przyczyny powodzeń i niepowodzeń szkolnych, H. Radlińska (red.), Warszawa, „Nasza Księgarnia" Sp. Akc. Związku Nauczycielstwa Polskiego, s. 4-5.

Radlińska H. (1948) Od Wydawców w: K. Zawistowicz-Adamska, Żywe tradycje współdziałania wsi, Łódź, Polski Instytut Służby Społecznej, s. 3-5.

Radlińska H. (1958) Przedmowa do wydania pierwszego w: K. Zawistowicz-Adamska, Społeczność wiejska. Wspomnienia i materiały z badań terenowych: Zaborów 19371938 (Wydanie 2. przejrz. i uzup.), Warszawa, Ludowa Spółdzielnia Wydawnicza, s. 13-14.

Radlińska H. (1979) Twórcza siła tradycji na wsi w: Oświata i kultura wsi polskiej. Wybór pism, oprac. H. Brodowska, L. Wojtczak, Warszawa, Ludowa Spółdzielnia Wydawnicza, s. 219-220.

Rembierz M. (2012) Dom rodzinny jako przestrzeń wychowania intelektualnego wzrastanie $w$ mądrości czy utwierdzanie się $w$ dziedziczonych uprzedzeniach i stereotypach w: Jaka rodzina takie społeczeństwo. Wspólnototwórczy wymiar wychowania intelektualnego, M. T. Kozubek (red.), Katowice, Księgarnia św. Jacka, s. 225-255.

Rembierz M. (2013) Kulturowe dziedzictwo Beskidów i kształtowanie osobowej tożsamości w interpretacji Jana Szczepańskiego w: Beskidzkie dziedzictwo, S. Cader, T. Kowalik (red.), Szczyrk, Beskidzki Instytut Nauk o Człowieku, s. 97-110. 
Ricoeur P. (2003a) Krytyka i przekonanie. Rozmowy z François Azouvim i Markiem de Launay, tłum. M. Drwęga, Warszawa, Wydawnictwo KR.

Ricoeur P. (2003b) O sobie samym jako innym, przeł. B. Chełstowski, Warszawa, Wydawnictwo Naukowe PWN.

Sacks O. (1996) Mroczek: zapominanie i pomijanie w nauce w: O. Sacks, J. Miller, S. J. Gould, D. J. Kevles, R. C. Lewontin, Ukryte teorie nauki, tłum. A. Pawelec, Kraków, Wydawnictwo „Znak”, s. 93-122.

Smolińska-Theiss B. (2015) Pedagogika społeczna w Polsce z perspektywy zjazdów pedagogicznych, „Pedagogika Społeczna”, nr 2, s. 39-51.

Theiss W. (1994/1995) Heleny Radlińskiej koncepcja badania i działania w: Helena Radlińska. Człowiek i wychowawca, I. Lepalczyk, B. Wasilewska (red.), Warszawa, Wydawnictwo Wolnej Wszechnicy Polskiej, s. 17-32.

Wejland A. P. (2004) Jak żegnać lokalne paradygmaty. O metodologii wywiadu i naukowych wspólnotach dyskursu, „Kultura i Społeczeństwo”, nr 1, s. 207-220.

Wyka A. (1993) Badacz społeczny wobec doświadczenia, Warszawa, Instytut Filozofii i Socjologii PAN.

Witkowski L. (2009a) Wyzwania autorytetu w praktyce społecznej i kulturze symbolicznej. Przechadzki krytyczne w poszukiwaniu dyskursu dla teorii, Kraków, Oficyna Wydawnicza „Impuls”.

Witkowski L. (2009b) Ku integralności edukacji i humanistyki II. Postulaty, postacie, pojęcia, próby, Toruń, Wydawnictwo Adam Marszałek.

Wrzosek W. (1995) Historia - kultura - metafora. Powstanie nieklasycznej historiografii, Wrocław, Fundacja na Rzecz Nauki Polskiej.

Zawistowicz-Adamska K. (1948) Społeczność wiejska. Doświadczenia i rozważania $z$ badań terenowych $w$ Zaborowie, Warszawa, Polski Instytut Służby Społecznej.

Zawistowicz-Adamska K. (1958) Społeczność wiejska. Wspomnienia i materiały z badań terenowych: Zaborów 1937-1938 (Wydanie 2. przejrz. i uzup.), Warszawa, Ludowa Spółdzielnia Wydawnicza. 